\title{
INSTRUMEN PEMAKSA ATAS KETIDAKPATUHAN TERGUGAT
}

\author{
Ahmad Trialdi \\ ahmadtrialdi99@gmail.com \\ 1910003600033
}

\section{Universitas Ekasakti}

\section{A. PENDAHULUAN}

Indonesia adalah Negara Hukum,sebagaimana ditegaskan dalam ketentuan Pasal 1 ayat (3) Undang-Undang Dasar Negara Republik Indonesia Tahun 1945(UUD 1945). Sebagai negara hukum Indonesia menganut konsepsi welfare state (negara kesejahteraan), sebagaimana diisyaratkan dalam alineakeempat Pembukaan UUD 1945, yang merupakan tujuan negara. Dalam konsepsi welfare state, pemerintah diberi wewenang yang luas untuk campur tangan (staatsbemoeienis) di segala lapangan kehidupan masyarakat dalam rangka menyelenggarakan kesejahteraan umum (bestuurszorg). Campur tangan tersebut tertuang dalam ketentuan perundangundangan, baik dalam bentuk undang-undang, maupun peraturan pelaksanaan lainnya yang dilaksanakan oleh administrasi negara, selaku alat perlengkapan negara yang menyelenggarakan tugas servis publik.

Negara hukum pada dasarnya terutama bertujuan untuk memberikan perlindungan hukum bagi rakyat. Perlindungan hukum bagi rakyat terhadap tindakan pemerintahan dilandasi oleh dua prinsip; prinsip hak asasi manusia dan prinsipnegara hukum.

Dalam negara hukum, setiap penyelenggaraan urusan pemerintahan haruslah berdasarkan pada aturan hukum yang berlaku (wetmatigheid van bestuur). Sebagai konsekuensi dari negara hukum, wajib adanya jaminan bagi administrasi negara sebagai alat perlengkapan negara untuk dapat menjalankan pemerintahan dan warga negara memiliki hak dan kewajiban mendapat jaminan perlindungan. Oleh karena itu, 
kekuasaan pemerintah tidak dapat lepas dari perkembangan asas legalitas yang telah dimulai sejak konsep negara hukum klasikformele rechtstaatatau liberale rechtsstaatyaitu wetmatigheid van bestuurartinya pemerintahan menurutundangundang. Setiap tindakan pemerintah harus berdasarkan kepada undang-undang.

Peradilan administrasi di Indonesia diwujudkan dengan Peradilan Tata Usaha Negara. Indonesia merupakan suatu negara hukum, dimana Negara hukum itu menginginkan keadilan dan perlindungan hukum bagi warga negaranya, baik dari sengketa antar warga negaranya maupun dengan pejabat negara yang ada. Untuk menjamin keadilan warga negara dari pejabat negara maka didirikanlah Pengadilan Tata Usaha Negara dengan diundangkannya Undang-Undang Nomor 5 Tahun 1986 Tentang Peradilan Tata Usaha Negara. Pengadilan Tata Usaha Negara berada dibawah sebuah Mahkamah Agung. Terbentuknya Peradilan Tata Usaha Negara berdasarkan Undang-Undang Nomor 5 Tahun 1986 merupakan amanat langsung dari Pasal 10 Undang-Undang Nomor 14 Tahun 1970 Tentang Pokok Kekuasaan kehakiman. Kekuasaan Kehakiman di Indonesia adalah kekuasaan negara yang Merdeka untuk menyelenggarakan peradilan guna menegakkan hukum dan keadilan. Adanya Peradilan Administrasi pada suatu negara merupakan suatu bukti bahwa negara tersebut menganut sistem demokrasi, karena dengan adanya peradilan administrasi dapat menjamin perlindungan atas hak warga negara dan dapat mengawasi kewenangan pemerintahan.

Sejatinya Peradilan Tata Usaha Negara di Indonesia baru terealisasi pada Tahun 1990 setelah diundangkannya Undang-Undang No 10 Tahun 1990 Tentang Pembentukan Pengadilan Tinggi Tata Usaha Negara Jakarta, Medan dan Ujung Pandang dan disahkannya Keputusan Presiden Nomor 52 Tahun 1990 Tentang 
Pembentukan Peradilan Tata Usaha Negara di Jakarta, Medan, Palembang, Surabaya dan Ujung Pandang.

Setelah 14 tahun berdiri ternyata terdapat beberapa kelemahan pada Pengadilan Tata Usaha Negara di Indonesia. Beberapa kelemahan itu adalah seperti tidak adanya lembaga eksekutorial putusan, kekuatan memaksa dan upaya paksa terhadap Putusan Pengadilan Tata Usaha Negara yang telah berkekuatan hukum tetap. Hal ini menyebabkan banyaknya Pejabat Negara Tata Usaha yang tidak melaksanakan Putusan karena pelaksanaan putusan hanya didasarkan pada kesadaran diri pejabat Tata Usaha Negara sendiri.

Dalam Pasal 115 Undang-Undang Peradilan Tata Usaha Negara disebutkan bahwa hanya putusan pengadilan yang telah memperoleh kekuatan hukum tetap yang dapat dilaksanakan. Putusan pengadilan yang belum memperoleh kekuatan hukum tetap tidak memiliki kekuatan eksekusi atau dengan kata lain putusan pengadilan yang masih mempunyai upaya hukum tidak dapat dimintakan eksekusinya.

Putusan Pengadilan Tata Usaha Negara seperti tidak ada kekuatan, karena Pejabat Tata Usaha Negara dalam melaksanakan Putusan hanya berdasarkan kesadaran diri saja. Lebih lanjut Lotulung menjelaskan bahwa pada dasarnya eksekusi di Pengadilan Tata Usaha Negara menekankan pada self respect dan kesadaran hukum dari pejabat Tata Usaha Negara terhadap isi putusan hakim untuk melakukannya dengan sukarela tanpa adanya upaya pemaksaan yang langsung dapat dirasakan dan dikenakan oleh pihak pengadilan terhadap pejabat Tata Usaha Negara yang bersangkutan. Ini serasa tidak adil bagi para pencari keadilan, karena tidak adanya efek jera bagi para Pejabat Tata Usaha Negara tersebut.

Lalu pada Tahun 2004 diundangkanlah Undang-Undang Nomor 9 Tahun 2004 Tentang Perubahan atas Undang-Undang Nomor 5 Tahun 1986 Tentang Peradilan 
Tata Usaha Negara. Namun dengan di Undangkannya Undang-Undang inipun permasalahan pada Pengadilan Tata Usaha Negara belum dapat teratasi. Hingga diundangkan lagi Undang-Undang Nomor 51 Tahun 2009 Tentang Perubahan Kedua atas Undang-Undang Nomor 5 Tahun 1986 Tentang Peradilan Tata Usaha Negara pun pengadilan Tata Usaha Negara masih menyisakan permasalaan mengenai upaya paksa pelaksanaan Putusan Pengadilan Tata Usaha Negara yang telah memiliki kekuatan hukum tetap.

Dengan lahirnya undang-undang nomor 9 tahun 2004 yang dirubah dengan undang-undang nomor 51 tahun 2009, maka dikenallah upaya paksa pada putusan Pengadilan Tata Usaha Negara. Pasal 116 ayat (4) 'Dalam hal tergugat tidak bersedia melaksanakan putusanpengadilan yang telah memperoleh kekuatan hukum tetap, terhadap pejabat yang bersangkutan dikenakan upaya paksa berupa pembayaran sejumlah uang paksa dan/atau sanksi administratif. Namun, hingga saat ini aturan pelaksanaan maupun petunjuk teknis bagaimana kedua instrumen upaya paksa tersebut dilaksanakan belum diterbitkan baik oleh pemerintah maupun oleh Mahkamah Agung sebagai dua pihak yang berwenang membentuk aturan yang dimaksud.

\section{B. PEMBAHASAN}

Selama ini putusan peradilan tata usaha negara hanya dianggap macan ompong karena banyak putusannya yang tidak dapat dieksekusi. Pandangan tersebut tentunya berpijak pada kenyataan, bahwa diperadilan lain, setelah suatu putusan berkekuatan hukum tetap, maka putusan tersebut dapat segera dieksekusi, yang bila mana perlu dapat dieksekusi secara paksa (rieel eksekusi). Sementara di Peradilan tata usaha negara, kenyataannya lain. Setelah menang di pengadilan Tata Usaha Negara dan putusan telah berkekuatan hukum tetap (in kracht van gewijsde), apabila pejabat Tata 
Usaha Negara dihukum tidak mematuhi putusan tersebut, maka si pemenang tidak bisa segera menikmati manfaat dari kemenangannya itu. Dalam keadaan seperti ini ternyata Peradilan tata usaha negara tidak dapat berbuat apa-apa, karena lembaga eksekusi secara normative dalam UU No. 5 Tahun 1986 yang dirumuskan secara mengambang (floating norm) tidak dapat memaksa pejabat untuk mematuhi putusan, hal ini tidak efektif untuk menghadapi Pejabat Tata Usaha Negara yang tidak mematuhi putusan Hakim Peradilan tata usaha negara.

Pada umumnya tidak ada gunanya memasukkan kewajiban-kewajiban atau larangan-larangan bagi para warga di dalam peraturan perundang-undangan tata usaha negara, manakala aturan-aturan tingkah laku itu tidak dapat dipaksakan oleh Tata Usaha Negara. Peran penting pada pemberian sanksi di dalam hukum administrasi memenuhi hukum pidana. Kebanyakan sistem perizinan menurut perundangundangan memuat ketentuan penting yang melarang para warga bertindak tanpa izin. Bagi para pembuat peraturan penting untuk tidak hanya melarang tindakan-tindakan yang tanpa disertai izin, tetapi juga terhadap tindakan-tindakan yang bertentangan dengan peraturan perundang-undangan yang dapat dikaitkan pada suatu izin, termasuk sanksi-sanksi administrasi yang khas, antara lain:

1. Bestuursdwang/paksaan pemerintah

2. Penarikan kembali putusan yang menguntungkan

3. Pengenaan denda administratif

4. Pengenaan uang paksa oleh pemerintah/dwangsom

Normativisasi hukum tidak cukup hanya sekedar memuat perintah dan larangan. Dibalik larangan, terutamanya harus ada ketentuan sanksi atas ketidakpatuhan. Karena sanksi hukum sampai saat ini masih merupakan alat yang paling ampuh untuk menjaga wibawa hukum atau dengan kata lain agar setiap orang 
patuh terhadap hukum. Ketidakpatuhan badan atau pejabat tata usaha negara untuk melaksanakan putusan pengadilan tata usaha negara sedikit banyak dapat mempengaruhi kewibawaan pengadilan, pelecehan terhadap peradilan, dan bukan mustahil jika ketidakpatuhan itu terjadi berulang- ulang, maka masyarakat semakin tidak percaya kepada pengadilan.

Pada azasnya suatu putusan hakim yang sudah mempunyai kekuatan hukum tetap harus dijalankan, akan tetapi terdapat penyimpangan terhadap azas ini seperti yang diatur dalam pasal $180 \mathrm{HIR}$, bahwa tidak semua putusan yang sudah mempunyai kekuatan hukum harus dijalankan, karena yang perlu dilaksanakan hanyalah putusanputusan yang bersifat condemnatoir,yaitu yang mengandung perintah kepada suatu pihak untuk melakukan suatu perbuatan.

Urgensi upaya paksa adalah sebagai penjamin kepastian hukum sebagai asas umum pemerintahan yang layak, yaitu negara hukum yang mengutamakan landasan peraturan perundang-undangan, kepatutan dan keadilan dalam setiap kebijakan penyelenggara negara. Kepastian hukum menghendaki dihormatinya hak yang telah diperoleh seseorang berdasarkan suatu keputusan pemerintah meskipun keputusan itu salah.

Menurut P.Nicolai dan kawan-kawan; ' Sarana penegakan hukum administrasi berisi 1. Pengawasan bahwa organ pemerintahan dapat melaksanakan ketaatan pada atau berdasarkan undang-undang yang ditetapkan secara tertulis dan pengawasan terhadap keputusan yang meletakkan kewajiban kepada individu; dan 2 penerapan kewenangan sanksi pemerintahan’.

Menurut Ten Berge yang dikutip oleh Philipus.M.Hadjon, yang menyebutkan bahwa instrumen penegakkan hukum adminstrasi meliputi pengawasan dan 
penegakan sanksi. Pengawasan merupakan langkah preventif untuk memaksakan kepatuhan, sedangkan penerapan sanksi merupakan langkah represif untuk memaksakan kepatuhan. Sanksi merupakan inti dari penegakan hukum administrasi. Sanksi biasanya diletakkan pada bagian akhir setiap peraturan. Sanksi diperlukan untuk menjamin penegakan hukum administrasi. Lemahnya putusan pengadilan tata usaha negara memang dikarenakan tidak adanya upaya paksa, hal ini bisa dilihat banyaknya putusan pengadilan tata usaha negara yang tidak dilaksanakan oleh badan/pejabat tata usaha negara.

Beberapa kasus Terkait Pelaksanaan Putusan Pengadilan Tata Usaha Negara: Terdapat beberapa contoh kasus pada Pengadilan Tata Usaha Negara yang tidak bisa dieksekusi dikemukakan oleh Dr.Lintong Oloan Siahaan saat beliau masih menjabat sebagai ketua pengadilan tinggi tata usaha negara medan dan sumber lainnya;

1. Penjatuhan sanksi uang paksa kepada bupati kabupaten siak atas kasus jembatan, sebanyak Rp.50.000.000/hari sampai pejabat tersebut melaksanakan putusan pengadilan tersebut, walaupun pada tingkat mahkamah agung keputusan ini dibatalkan.

2. Sengketa pengelolaan sarang burung di tabalong yang telah diputus pada tahun 1994, meskipun telah melalui prosedur eksekusi sampai tingkat presiden, ternyata bupati tabalong tetap tidak melaksanakan putusan peradilan tata usaha negara tersebut.

3. Kasus perparkiran di kota medan, meskipun kepala dinas perparkiran kota madya medan telah dihukum untuk mencabut keputusan yang diterbitkannya oleh pengadilan tata usaha negara medan dan telah dilakukan peneguran sampai tingkat presiden, ternyata pihak dinas perparkiran tidak melaksanakan putusan hakim tersebut. 
4. Kasus pembongkaran restoran bali Sky Ligth Restaurant dimana bupati Gianyar Bali nekat membongkar restoran tersebut, padahal sebelumnya pengadilan tata usaha negara telah memerintahkan agar surat perintah bongkar yang diterbitkannya cacat hukum dan dinyatakan batal.

Kasus lain adalah kasus yang terjadi di PangkalPinang antara Imiyardi dan Abubakar melawan Komisi Pemilihan Umum Kota PangkalPinang dengan nomor perkara yang didaftarkan 18/G/2013/PTUN.PLG Pengadilan Tata Usaha Palembang mengabulkan permohonan penggugat yang isinya;

1. Mengabulkan gugatan para Penggugat untuk sebagian.

2. Menyatakan batal keputusan Nomor 30/Kpts-Kota-009.436512/2013 Tentang Penetapan Pasangan Calon Yang Memenuhi Persyaratan Sebagai Peserta Dalam Pemilihan Umum Walikota Dan Wakil Walikota Pangkalpinang Tahun 2013 tertanggal 26 April 2013.

3. Memerintahkan kepada Tergugat untuk mencabut keputusan Komisi Pemilihan Umum Kota Pangkalpinang nomor 30/Kpts-Kota009.436512/2013 Tentang Penetapan Pasangan Calon Yang Memenuhi Persyaratan Sebagai Peserta Dalam Pemilihan Umum Walikota Dan Wakil Walikota Pangkalpinang Tahun 2013 tertanggal 26 April 2013.

4. Memerintahkan kepada Tergugat untuk menerbitkan keputusan baru pengganti keputusan Komisi Pemilihan Umum Kota Pangkalpinang nomor 30/Kpts-Kota-009.436512/2013 Tentang Penetapan Pasangan Calon Yang Memenuhi Persyaratan Sebagai Peserta Dalam Pemilihan Umum Walikota Dan Wakil Walikota Pangkalpinang Tahun 2013 tertanggal 26 April 2013 dan memasukkan para penggugat sebagai daftar calon Walikota dan Wakil Walikota Pangkalpinang. 
Komisi Pemilihan Umum Kota Pangkalpinang merasa tidak puas atas hasil putusan Pengadilan Tata Usaha Palembang dan mengajukan Banding ke Pengadilan Tinggi Tata Usaha Negara Medan, yang mana hasil putusan Pengadilan Tinggi Tata Usaha Negara Medan menguatkan putusan Pengadilan Tata Usaha Palembang.

Namun Komisi Pemilihan Umum Kota Pangkalpinang tetap enggan untuk melaksanakan putusan pengadilan. Dan tetap melaksanakan pemilihan tanpa memasukkan nama penggugat. Meski putusan tersebut tetap memenangkan pasangan Ismiryadi dan Abu Bakar agar tetap dapat ikut dalam pelaksanaan Pilkada, namun hingga Pilkada digelar, Komisi Pemilihan Umum Pangkalpinang tidak juga melaksanakan putusan Pengadilan Tata Usaha Negara.

Pada kasus lain yang ditemukan oleh Adrian W.Bedner dalam studi kasusnya ada 26 kasus noneksekusi, yaitu;

1. Lima perkara penggusuran ; Jalan Lawang Seketeng, Pasar Ampara Di Jayapura, PT Pelni, Pasar Perbaungan Dan Kawasan Sunter.

2. Sembilan pembongkaran; Jalan Jenderal Sudirman, Bali Sky Light, Tanah Merah, PT Pelni, Rumah Satu Milyar Di Bogor, Klender, Tanjung Morawa, Majapahit Permai Dan Otong Jalihin.

3. Enam tentang IMB; Jalan Jenderal Sudirman, PT Dharma Winata Karya, Abdul Muis, Batavia City, Tanah Abang, STM Jember Dan Satu Izin Operasi; PT Toha Semangat.

4. Tiga izin mengumpulkan sarang burung walet; Lahat, Teberong, Berau.

5. Satu tentang masuk kembalinya dua mahasiswa ke Universitas; Universitas Hasanuddin.

6. Satu tentang pelelangan; Soegondo. 
Contoh kasus diatas menjadi bukti betapa lemahnya putusan pengadilan tata usaha negara, dan menunjukkan betapa tidak berdayanya sebuah produk hukum pengadilan ketika berhadapan dengan pejabat administrasi pemerintahan dan seberapa besar ketidak patuhan Pejabat Tata Usaha Negara dalam melaksanakan Putusan Pengadilan. Lazimnya yang dikatakan sebagai ketidakpatuhan pada putusan sebenarnya adalah ketidakpatuhan pada perintah penundaan. Angka ketidakpatuhan sebesar 60 persen (yang disebutkan oleh Ketua Pengadilan Tinggi Tata Usaha Negara pada Media Indonesia,31 Juli 1996).

Para hakim tidak memiliki banyak informasi mengenai ketidakpatuhan Pejabat, mereka hanya mendapat informasi ketika penggugat mengajukan permohonan eksekusi. Hasil dari eksekusi ini biasanya adalah surat dari Pejabat yang lebih tinggi kepada tergugat dengan instruksi untuk melaksanakan putusan.

Banyak kasus ketidakpatuhan terhadap putusan yang dilaporkan di media. Hal ini merupakan salah satu penghinaan terhadap pengadilan Tata Usaha Negara. Untuk apa suatu pengadilan dibentuk bila putusannya tidak dilaksanakan. Tujuan para penggugat mengajukan gugatannya ke Pengadilan Tata Usaha Negara adalah untuk mencari keadilan. Namun disaat penggugat telah mendapatkan kemenangannya, ternyata putusan pengadilan tersebut tidak dapat dilaksanakan karena putusan Pengadilan Tata Usaha Negara hanya berdasarkan pada rasa kesadara diri dari Pejabat Tata Usaha Negara. Agar putusan Pengadilan Tata Usaha Negara dihormati oleh para tergugat, maka upaya paksa sangat penting untuk diterapkan dalam rangka menjaga marwah Pengadilan Tata Usaha Negara. 
Permasalahan upaya paksa dalam pelaksanaan putusan Pengadilan Tata Usaha Negara. Setidaknya ada beberapa hal yang menjadi kendala dalam pelaksanaan upaya paksa di Pegadilan Tata Usaha Negara Pekanbaru.

1. Tidak adanya juklak atau petunjuk pelaksanaan upaya paksa. Setelah dilakukan perubahan pertama yaitu melalui Undang-Undang Nomor 9 Tahun 2004 Tentang Perubahan Pertama Atas Undang-Undang Nomor 5 Tahun 1986 Tentang Peradilan Tata Usaha Negara, maka pada pasal 116 dikenallah upaya paksa pada Peradilan Tata Usaha Negara. Sampai saat ini belum ada mengenai peraturan pelaksanaan upaya paksa pada putusan pengadilan tata usaha negara yang telah berkekuatan hukum tetap. Upaya paksa yang dimaksud berupa uang paksa dan sanksi administratif.

Mengenai uang paksa terdahulu dikenal dalam hukum acara perdata, yaitu dwangsom. Pengaturan uang paksa sendiri tidak diatur dalam HIR/Rbg. Pelaksanaan uang paksa diatur dalam pasal 606a dan 606b Rv. Namun apakah ketentuan Rv masih tetap dapat dilaksanakan pada praktik peradilan mengingat $\mathrm{Rv}$ sudah dinyatakan tidak berlaku lagi. Secara teoritis kentuan dalam rv dinyatakan sudah tidak berlaku lagi karena telah dihapusnya Raad van Juaticie dan Hoogerechtshof.

2. Minimnya laporan perkembangan pelaksanaan dan/atau minimnya permohonan pelaksanaan suatu Pengadilan TUN yang telah berkekuatan hukum tetap. Sampai saat ini Pengadilan TUN masih kesulitan mencatat berapa putusan yang sudah dieksekusi. Pengadilan TUN hanya mampu mencatat data apabila ada pengajuan permohonan eksekusi dari pihak penggugat. Sementara jika tidak ada pengajuan permohonan oleh 
penggugat, maka Pengadilan TUN sangat sulit mengetahui apakah suatu putusan telah dieksekusi atau tidak.

Menurut Beni Suryadi, selama ini kurangnya partisipasi dari pihak yang bersengketa telah menyebabkan pengadilan tidak bisa memastikan apakah suatu putusan pengadilan TUN yang telah berkekuatan hukum tetap telah dilaksanakan. Syamsir Yusfan kemudian menambahkan bahwa secara praktis sejak disahkannya UU No.9 Tahun 2004, di lingkungan Pengadilan TUN Padang sendiri belum pernah ada permohonan dari pihak penggugat agar suatu putusan TUN yang telah berkekuatan hukum tetap dilaksanakan. Dengan demikian dapat disimpulkan bahwa pelaksanaan putusan menjadi tidak efektif sama sekali meskipun oleh undang-undang telah digariskan bahwa pelanggarnya dapat dibebankan upaya paksa jika putusan tersebut tidak dilaksanakan. Kendala utamanya adalah tidak adanya partisipasi aktif dari tergugat untuk melaporkan pelaksanaan putusan Pengadilan TUN yang bersangkutan.

3. Diperlukan adanya anggara khusus baik di dalam APBD maupun APBN, menurut panitera pengadilan Tata Usaha Negara Padang, Beni Suryadi.24Namun kembali dikarenakan tidak adanya peraturan pelaksana mengenai upaya paksa ini, sehingga APBD dan APBN belum bisa diadakan.

Ide/gagasan agar upaya paksa dapat terlaksana berupa pengenaan denda administratif dan uang paksa, maka;

1. Mutlak harus atas dasar peraturan perundang-undangan yang tegas. Peraturan tersebut dapat berupa; 
a) Penerbitan Peraturan Pemerintah tentang pelaksanaan upaya paksa.Terkait dengan tidak adanya penjelasan mengenai tata cara pelaksanaan upaya paksa pada undang-undang nomor 51 tahun 2009, maka peraturan pemerintah dapat menjelaskan bagaimana pelaksanaannya. Walaupun dalam undang-undang tidak meminta secara tegas adanya peraturan pemerintah untuk menjelaskannya, namun bila dalam undang-undang tersebut diperlukan adanya penjelasan, hal ini dapat dilakukan.

b) Menerbitkan peraturan Mahkamah Agung Bila penerbitan peraturan pemerintah dianggap memakan banyak waktu dan dana yang besar. Maka Mahkamah Agung dapat mengeluarkan Peraturan Mahkamah Agung/ PERMA yang berisi penjelasan pelaksanaan upaya paksa agar dapat berjalan secara efektif.

2. Gagasan selanjutnya adalah dilakukan revisi terhadap Undang-undang nomor 51 tahun 2009, revisi undang-undang ini dimaksudkan agar upaya paksa dapat dilaksanakan secara efektif.

3. Sejak tahun 2007 sebenarnya telah dipersiapkan Rancangan undangundang Administrasi Pemerintahan yang didalamnya juga mengatur mengenai pelaksanaan-pelaksanaan upaya paksa suatu putusan pengadilan tata usaha negara. Rancangan Undang-Undang ini terdiri dari 10 bab dan 45 pasal. Agar upaya paksa dapat berjalan efektif, diharapkan rancangan undang-undang ini dapat segera disahkan.

4. Bila bercermin kepada peradilan administrasi Thailand, Indonesia dalam pelaksanaan bisa dikatakan sangat tertinggal. Karena peradilan 
administrasi Thailand jauh lebih matang, walaupun peradilannya bary terbentuk pada tahun 2001 .

Meskipun peradilan administrasi Thailand baru dibentuk pada tahun 2001 namun sebenarnya keberadaannya suda ada sejak lama. Keberadaan peradilan Administrasi Thailand dapat ditelusuri dari sejak tahun 1874. Menurut Dr. Lintong O Siahaan,Thailand bukan hanya mengenal lembaga uang paksa namun lebih menguasainya. Hal ini dapat disebabkan karena negara Thailand merupakan binaan dari negara Jerman, bukan dari Negara Prancis seperti Indonesia. Pengadilan Administrasi Thailand berwenang;

1. Dalam hal keputusan pejabat melanggar hukum,pengadilan dapat memerintahan pencabutan keputusan atau penundaan sebagian atau seluruhnya;

2. Dalam hal pejabat melakukan suatu kelalaian atau penunda pelayanan dengan tidak masuk akal, maka pengadilan dapat memerintahkan pimpinan pejabat administrasi yang bersangkutan untuk melakukan suatu kewajiban yang ditentukan oleh pengadilan;

3. Dalam hal keputusan diterbitkan melanggar hukum atau menyalahi kewajibannya atau berkaitan dengan kontrak administrasi maka pengadilan dapat memerintahkan pembayaran sejumlah uang atau penyerahan barang atau melakukan atau tidak melakukan suatu perbuatan dengan atau tanpa memberi jangka waktu atau keadaan /kondisi tertentu;

4. Berkaitan dengan suatu permohonan mengenai hak dan kewajiban seseorang, maka pengadilan dapat memerintahkan pemulihan hak dan kewajiban; 
5. Memerintahkan seseorang untuk melakukan atau tidak melakukan sesuatu yang ditentukan hukum.

Dari kewenangan pengadilan administrasi Thailand diatas kita dapat melihat bahwa kewenangannya lebih matang daripada Indonesia, karena menetapkan sanksi yang jelas terhadap pejabatnya. Di negara Thailand putusan pengadilan yang berisi pembatalan keputusan pejabatnya diumumkan di lembaran negaranya. Untuk putusan pengadilan yang berupa pembayaran sejumlah uang atau penyerahan barang maka pengadilan dapat melakukan eksekusi terhadap harta kekayaan yang bersangkutan. Dalam hal putusan pengadilan berupa suatu perintah untuk melakukan atau tidak melakukan suatu perbuatan, maka pengadilan dapat melakukan eksekusi dengan menggunakan hukum acara perdata secara mutatis mutandis.Karena peradilan administrasi Thailand lebih matang dari Indonesia maka Indonesia bisa mencontoh Thailand mengingat sistem peradilan Thailand dan Indonesia hampir sama.

Pembentukan peraturan pelaksana mengenai pelaksanaan upaya paksa sangat dibutuhkan agar upaya paksa tidak hanya menjadi suatu syarat suatu peraturan melainkan dapat diwujudkan dan di implementasikan, sehingga para pencari keadilan di pengadilan tata usaha negara bisa mendapatakan keadilan mereka.

\section{PENUTUP}

Pembahasan yang telah diuraikan sebelumnya memberikan penulis beberapa kesimpulan yang dapat diambil, yaitu sebagai berikut;

a) Hanya putusan yang telah berkekuatan hukum tetap yang dapat di laksanakan.

b) Banyak putusan pengadilan tata usaha negara yang tidak bisa dieksekusi, disebabkan oleh faktor-faktor, baik dari sisi kesadaran pejabat tata usaha 
negara maupun tidak adanya lembaga upaya paksa pada pengadilan tata usaha negara.

c) Upaya paksa sebagaimana yang telah diamanatkan dalam Pasal 116 undang-undang nomor 51 tahun 2009 ternyata belum dapat terlaksana secara efektif terkait belum adanya peraturan pelaksana mengenai upaya paksa itu sendiri.

d) Penerapan upaya paksa ini sebagai suatu ciri terlaksananya asas-asas umum pemerintahan yang layak, yaitu kepastian hukum. Kepastian hukum bagi para pencari keadilan agar apa yang telah diputus oleh pengadilan tata usaha negara benar-benar dapat diterapkan. Dan juga upaya paksa ini sebagai senjata agar pejabat negara mau melaksanakan putusan pengadilan sebagai bukti suatu penegakan hukum.

Agar upaya paksa dapat dilaksanakan maka:

a) Perlu ada peraturan pelaksana mengenai upaya paksa itu sendiri. seperti

1) Penerbitan Peraturan Pemerintah tentang pelaksanaan upaya paksa.

2) Menerbitkan peraturan Mahkamah Agung

b) Mengesahkan draft Rancangan undang-undang Administrasi Pemerintahan yang didalamnya juga mengatur mengenai pelaksanaan-pelaksanaan upaya paksa suatu putusan pengadilan tata usaha negara. Rancangan UndangUndang ini terdiri dari 10 bab dan 45 pasal.

c) Partisipasi dari tergugat sangat diperlukan dalam pelaksanaan putusan pengadilan tata usaha negara, untuk mengetahui sejauh mana perkembangan dari suatu eksekusi. 


\section{DAFTAR PUSTAKA}

Abdullah, Rozali, 2013, Hukum Acara Peradilan Tata Usaha Negara, Cetakan Keduabelas, PT. Rajawali Grafindo, Jakarta.

Asikin, Zainal, 2012, Pengantar Tata Hukum Indonesia, PT Raja Grafindo Persada, Jakarta.

Harahap, Zairin, 2005 Hukum Acara peradilan Tata Usaha Negara,Rajawali Pers, Jakarta.

M. Hadjon, Philipus Dkk, 2008, Pengantar Hukum Administrasi Indonesia,Cetakan Kesepuluh, Gadjah Mada University Press, Jogjakarata.

Mulyadi, Lilik, 2001, Tuntutan Uang Paksa Dwangsom Dalam Teori Dan Praktik, Djambatan, Jakarta.

http://cakimptun4.wordpress.com/2009/09/07/dwangsom-dalam-putusan-hakim-peratun$\begin{array}{lllll}\text { suatu-gagasan/ diakses terakhir tanggal } 14 & \text { Januari } 2014\end{array}$ http://www.ptun.palembang.go.id/ diakses terakhir pada 1 Februari 2021. 